\title{
AÇÕES DE LIBERDADE NA CIDADE DE CAMPINAS (1871-1888)
}

\author{
FREEDOM'S LAWSUIT AT CAMPINAS CITY (1871-1888)
}

\author{
${ }^{1}$ Fernanda Cristina Covolan
}

\section{RESUMO}

Esse trabalho se propõe a entender os caminhos seguidos para o escravo se tornar um sujeito ativo no Brasil oitocentista conquistando sua Liberdade por meio de ações judiciais, considerando os espaços legais que deram acesso a essa possibilidade. Inicialmente fez-se uma retrospectiva da legislação de 1871 e 1886, permitindo compreender como foram criadas as condições para que o escravo pudesse requerer sua liberdade sem a necessidade do consentimento do proprietário. Viu-se também que a referida legislação significou a diminuição das esferas de dependência do escravo que desejasse a liberdade, já que não mais dependia da vontade do senhor, podendo ele mesmo comprar sua liberdade. Por fim foram utilizados dados secundários, advindos de trabalhos historiográficos, bem como dados primários provenientes do arquivo do Tribunal de Justiça de Campinas, no Centro de Memória da Unicamp. Estes dados revelaram um crescimento no número de ações de liberdade ao longo dos anos, até a definitiva abolição em 1888.

Palavras-chave: Brasil imperial, Escravidão, Ações de liberdade

\begin{abstract}
This study aims to understand the ways followed by the slave in order to become an active subject in nineteenth-century Brazil, achieving their freedom through lawsuits, regarding the legal areas that enabled this possibility. Initially, it was made a retrospective of the 1871 and 1886 laws, allowing to understand how the environment has been created so that the slave could require their freedom without the consent of the owner. It was seen also that the mentioned laws meant the dependence decrease of the slave that wanted the freedom, since he no longer depended on the owner's will, the slave could buy himself his freedom. Finally, were used secondary data from historiographical studies as well as primary data from the Court of Justice of Campinas, stored in Unicamp Memory Center. These data revealed an increase in the number of freedom's lawsuit over the last years until the definitive abolition in 1888 .
\end{abstract}

Keywords: Brasil empire, Slavery, Freedom's lawsuit

\footnotetext{
${ }^{1}$ Doutoranda na Universidade Presbiteriana Mackenzie, São Paulo - SP (Brasil). Professora do Centro Universitário Adventista de Ensino - UNASP, São Paulo - SP (Brasil). E-mail: fernandacovolan@ hotmail.com
} 


\section{INTRODUÇÃO}

O Século XIX foi, provavelmente, o período mais significativo de mudanças para o Brasil, e em especial para a formação do Direito brasileiro, durante o qual o Brasil passa de Colônia a Reino, de Reino a Império independente, e então à República.

Além das mudanças da forma de governo, o direito brasileiro também observaria profundas modificações no que se refere ao sistema produtivo, antes baseado predominantemente na escravidão, e que a partir de meados do século XIX começa a ser juridicamente modificado, fechando-se as fontes de manutenção do sistema escravocrata ao mesmo tempo em que é revisto o sistema jurídico de propriedade e relações de trabalho.

De uma perspectiva legal, vários foram os movimentos feitos quanto à questão servil nos anos de 1831, 1845, 1850, 1871, 1879 e 1885, em ires e devires que revelavam o conflito existente entre as elites representadas no Congresso e no Conselho junto ao Imperador.

A legislação advinda a partir de 1850, por fim, estabeleceu um término previsível para a escravidão, ainda que as ideias de extinção gradativa não se tenham verificado. Além disso, porém, as leis sucessivas trouxeram algumas previsões de conquista de liberdade por outros meios antes não positivados, como a compra da própria liberdade, inclusive com arbitramento pericial do valor do escravo.

Antes desta previsão legal, a alforria dos escravos era prerrogativa exclusiva do senhor, que desta se utilizava com surpreendente frequência, muitas vezes recebendo pagamento do próprio escravo em dinheiro ou serviços futuros, mas também para justificar afetos, para libertar escravas cujas relações com o senhor haviam produzido frutos, ou mesmo para angariar a graça divina na hora da morte. Ou seja, também a concessão de liberdade por cartas de alforria servia como meio de afirmação do poder de vida e morte exercido pelo senhor.

Sendo assim, esse trabalho inquiriu sobre os espaços legais para a conquista de liberdade em que era sujeito ativo o próprio escravo, ainda que assistido nestas ações judiciais.

Objetivou-se então verificar inicialmente as formas de aquisição de liberdade, em especial o sistema de cartas de liberdade, bem como o advento as normas de 1871 e 1885, que positivaram o costume da compra da liberdade pelo próprio escravo. A seguir, buscou-se compreender de que maneira tais previsões legais foram apropriadas pelos interessados, os 
escravos, nas ações de liberdade que tramitaram no Brasil, em especial no então Tribunal de Justiça de Campinas.

Para tais estudos, a pesquisa assumiu o tipo documental e bibliográfico, baseando-se em dados secundários advindos da análise da literatura já publicada, mas também se serviu do arquivo do Tribunal de Justiça de Campinas, que se encontra sob os cuidados do Centro de Memória da Unicamp.

\section{Liberdade: o Costume e a Lei}

Até 1871 não havia uma lei que positivasse noções de cartas de liberdade, ou pecúlio, ou outras formas de mudar o status de escravidão. O que havia, além do direito costumeiro, principalmente nos lugares afastados das cidades, eram decretos e regulamentos que não passavam de colocações pontuais para determinadas tarefas. Ainda assim, essa era uma prática comum a denotar o poder de vida e morte sobre o escravo.

O direito costumeiro da época era o que ditava se o escravo podia ser livre ou não, afinal de contas, quem dava essa liberdade era o seu senhor. "Sempre, de qualquer forma, indenizavam-se os senhores, e cabia a estes a concessão da carta de alforria. Em suma, afora situação excepcional, competia exclusivamente ao senhor conceder alforria ou negá-la a seu escravo" (CUNHA, 1987, p. 126). O senhor poderia alforriar seu escravo por caridade, benevolência, por princípios da igreja, lembrando que "não só as ordens religiosas tinham seus escravos, até quase às vésperas da Abolição, mas algumas se especializaram, e parecem ter sido as únicas empresas do gênero no Brasil, na reprodução de escravos." (CUNHA, 1987, p. 129)

Para Manuela Carneiro Cunha (1987) a ausência de legislação seria proposital, teria a função específica de dar aos proprietários a prerrogativa de resolver a vida do seu escravo da forma que bem entender. Posto isso, o Estado "optava" pelo silêncio das leis, assim não se posicionava contra os fazendeiros e, como benefício adicional, dava aos proprietários a chancela sobre seus escravos. "O controle privado da alforria tinha, assim, uma importância crucial: não só mantinha a sujeição entre os escravos, mas permitia a produção de libertos dependentes." (CUNHA, 1987, p. 138).

A Lei Eusébio de Queiroz (Lei 581 de 4 de setembro de 1850), que colocou fim ao tráfico negreiro, fez antever o fim do sistema escravista no Brasil, em especial porque, diferentemente do que ocorrera com a legislação de 1831, foi posta em prática. Era 
pensamento comum entre os defensores do fim da escravidão no período que esta não poderia ser extinta repentinamente, sendo importante um sistema de extinção gradual, como se vê:

\begin{abstract}
A emancipação imediata, isto é, declarar desde logo livres todos os escravos existentes no Brasil, é solução absolutamente inadmissível na atualidade, e mesmo em futuro próximo; porque o grande número de escravos que ele ainda conta [...] é um obstáculo insuperável, visto como traria necessariamente a desorganização do trabalho, atacaria portanto a produção mais importante e a fonte mais poderosa da riqueza entre nós, introduziria a desordem nas famílias, e daria lugar a ataques à ordem pública, desenfreando-se tão grande número de escravos, tudo com grande dano particular e do Estado, assim como dos próprios escravos. (MALHEIRO, 1976, p. 153)
\end{abstract}

O fim do tráfico fechou uma das duas portas de manutenção do sistema, restando então a reprodução local da mão de obra, que será por sua vez extinta em 1871, em texto no qual a princesa regente

[...] concede liberdade às crianças nas cidades no país, de mãe escrava. A partir dessa data, e tendo em vista que a importação de escravos africanos está proibida, não mais deveria haver crianças escravas e a escravidão estava ameaçada de extinção gradual por falta de cativos. (MATTOSO, 2003, p. 176)

Segundo Ademir Gebara, a Lei Rio Branco (Lei n ${ }^{\circ} 2040$ de 28 de setembro de 1871, também conhecida como Lei do Ventre Livre) não era apenas um aspecto normativo e sim um ponto para a "formação de uma política de desescravização e organização do mercado de trabalho livre". (GEBARA, 1986, p. 61). A este trabalho interessam, porém, os demais aspectos positivados pela Lei Rio Branco, em especial a possibilidade de o escravo adquirir sua liberdade pelo pagamento de seu valor, com formação de pecúlio. Tem-se no art. $4^{\circ}$ da referida lei :

É permitido ao escravo a formação de um pecúlio com o que lhe provier de doações, legados e heranças, e com o que, por consentimento do senhor, obtiver do seu trabalho e economias. O governo providenciará nos regulamentos sobre a colocação e segurança do mesmo pecúlio.

Nesse caso a diferença encontrada era o fato de poder haver a alforria forçada, e a possibilidade de o senhor apenas discutir o preço a ser pago pelo escravo, ressalvando que, pelo art. $4^{\circ}, \S 2^{\circ}$ :

O escravo que, por meio de seu pecúlio, obtiver meios para indenização de seu valor, tem direito à alforria. Se a indenização não for fixada por acordo, o será por arbitramento. Nas vendas judiciais ou nos inventários o preço da alforria será o da avaliação. 
Outras mudanças no direito dos escravos aconteceram. A criação do Fundo de Emancipação tem ligação direta com a matrícula que passara a ser obrigatória em todo Império. Vide o art. $8^{\circ}$ e seu parágrafo $3^{\circ}$ da Lei do Ventre Livre:

Art. $8^{\circ}$ : O governo mandará proceder à matrícula especial de todos os escravos existentes no Império, com declaração de nome, sexo, estado, aptidão para o trabalho e filiação de cada um, se for conhecida.

$[\ldots]$

$\S 3^{\circ}$ : Pela matrícula de cada escravo pagará o senhor por uma vez somente o emolumento de quinhentos réis, se o fizer dentro do prazo marcado, e de mil réis, se exceder o dito prazo. $\mathrm{O}$ provento deste emolumento será destinado a despesas da matrícula, e o excedente ao fundo de emergência.

Os escravos eram matriculados com seus senhores pagando taxas. Essas taxas e negociações feitas em relação ao escravo eram guardadas nesse Fundo de Emancipação cuja verba seria revertida para eventual indenização dos proprietários que alforriassem seus escravos.

Assim, em que pesem as diversas interpretações historiográficas sobre o propósito e serviço prestado pela libertação do ventre, é certo que a positivação de meios de libertação que extrapolavam a mera liberalidade impactou as relações de dominância para os escravos, como os documentos analisados nesta pesquisa demonstraram.

Pena (1999, p. 275), diz que "as ações de arbitramento para liberdade abalaram um dos mecanismos mais tradicionais do controle social dos escravos, representado pela concessão exclusiva da alforria pelos senhores". Além do mais, "poderíamos citar ainda, por exemplo, no que diz respeito ao senhores, a obrigação de terem que matricular seus escravos nas coletorias, sob pena de multa.” (PENA, 1999, p. 279). Pelas listas feitas por todo Império, os escravos matriculados deram ao Estado provas de que muitos estavam ilícitos, visto que haviam entrado no país depois da lei de 1831, que positivara a extinção do tráfico mas que não fora cumprida.

Grinberg (1994, p. 98), por outro lado, defende a ideia de que a Lei do Ventre Livre atingiu uma faceta de "restrição a liberdade", uma vez que cerceou as maneiras de se chegar a ela, já que a utilização do sistema judicial funcionaria como empecilho, e não como sistema de acesso. Em contrapartida a lei trouxe em seu artigo $4^{\circ}, \S 9^{\circ}$, a derrogação da revogação de alforrias por ingratidão, o que pode ser considerada benesse ao escravo já que a possibilidade de reescravização por ingratidão mantinha fortemente a submissão do liberto ao senhor.

O que se verificou, com a positivação, foi a diminuição significativa das cartas de liberdade, como se vê na tabela a seguir, baseada nos dados trazidos por Bertin (2004), mas 
que se coaduna com os dados iniciais das pesquisas da autora ainda em curso junto ao $1^{\circ}$ Tabelionato de Notas da Cidade de Mogi Mirim.

Tabela 1 - Diferença entre os registros e alforrias entrados/dados aos escravos em São Paulo ${ }^{1}$

\begin{tabular}{|c|c|c|c|c|}
\hline Período & \multicolumn{2}{|c|}{ Registros } & \multicolumn{2}{c|}{ Alforrias } \\
\hline & Quantidade & Média Anual & Quantidade & Média Anual \\
\hline $1800-1850$ & 722 & 14,4 & 917 & 18,3 \\
\hline $1850-1871$ & 221 & 10,5 & 243 & 11,6 \\
\hline $\mathbf{1 8 7 1 - 1 8 8 8}$ & $\mathbf{1 6 2}$ & $\mathbf{9 , 5}$ & $\mathbf{1 7 8}$ & $\mathbf{1 0 , 5}$ \\
\hline TOTAL & 1.105 & 12,6 & 1.388 & 15,2 \\
\hline
\end{tabular}

Esta diminuição do número de cartas de liberdade parece dar suporte à ilação de Grinberg (1994), em sua afirmação de que Lei de 1871 teria sido o motivo para decréscimo de Cartas e Alforrias. Não resta dúvidas, seja a razão qual for, que a Lei de 1871 teve como consequência a diminuição das cartas de alforria, independentemente de ter sido este o seu propósito ou não.

A referida norma criou uma nova possibilidade, a de que a liberdade pudesse ser obtida por meios próprios, ou com auxílio econômico de terceiros, quer o proprietário concordasse, quer não, bastando que se fixasse o preço adequado. $\mathrm{O}$ escravo precisava ainda ser assistido no processo, visto não possuir capacidade civil, mas sua representação já não se dava exclusivamente pelo proprietário, reconhecendo-se assim implicitamente que este era parte contrária, interessada no resultado da causa, sendo impossível ocupar tal posição.

Ao mesmo tempo em que diminuem significativamente as concessões de liberdade nos registros dos tabelionatos, quando são tomados os dados das Ações de Liberdade que tramitaram no Tribunal de Justiça de Campinas o que se vê é que a partir de 1871 seu número aumentou significativamente. Antes de 1871 houve apenas 5 ações que discutiam a liberdade entre o escravo e o proprietário, enquanto que a partir deste ano foram 108 ações judiciais (ABRAHÃO, 1992).

Outro aspecto importante referido na bibliografia a respeito dos efeitos da Lei de 1871 seria seu poder de acalmar os abolicionistas, em especial acalmar eventuais movimentos violentos, já que as previsões da referida norma indicavam uma abolição gradual, mas efetiva:

\footnotetext{
1 Tirado do livro "Alforrias na São Paulo do Século XIX: Liberdade e Dominação" - analisados os casos no estado de São Paulo. $1^{\circ}$ e $2^{\circ}$ Cartórios, com 1.105 Cartas de Liberdade.
} 
Nesse sentido, uma das consequências mais importantes dessa legislação gerada em 1871, ainda não mencionada por pesquisadores do período, foi o efeito dela sobre os escravos. A lei, inequivocamente, conseguia a submissão e aquiescência dos escravos para o processo de emancipação gradualista. (GEBARA, 1986, p.72)

No entanto, são admissíveis outras visões, já que não são necessários atos de heroísmo para que se faça uma afirmação e contraposição ao sistema. As formas de se manifestar não se restringem à luta física ou à rebeldia, pois caso se enquadrasse nesses termos, as formas de atuação social seriam reduzidas. Sobreviver e resistir usando o sistema poderia ser também uma estratégia não violenta, outra frente de atuação além da força, pela qual a norma positivada é usada como instrumento de luta, invertendo os pressupostos de que o ordenamento jurídico serve apenas aos interesses das elites.

A Lei de 1871 não foi suficiente para acalmar os ânimos abolicionistas, antes parece ter tido efeito contrário, já que estes se acirraram, pelo que o Império procura retomar as rédeas do processo com a Lei ${ }^{\circ} 3.270$, de 28 de setembro de 1885 , que ficou conhecida como Lei dos Sexagenários ou Lei Saraiva-Cotegipe.

Essa lei trouxe quatro importantes modificações: (a) a liberdade dos escravos maiores de sessenta anos; (b) tabela de preços previamente estipulados para pagamento do pecúlio e conquista da liberdade; (c) a nova matrícula para os escravos, sendo que essa terceira e a segunda se confundem, visto que de acordo com a idade relatada seria fixado o preço do escravo; e por fim (d) a reelaboração do sistema de taxas para o Fundo de Emancipação.

A começar pela liberdade dos escravos pela idade, a Lei Saraiva-Cotegipe dizia que todos os escravos com mais de sessenta anos seriam considerados livres, ainda que as exigências do texto na verdade significassem a liberdade a partir dos sessenta e cinco anos:

Art. $3^{\circ}, \S 10$ - São libertos os escravos de 60 anos de idade, completos antes e depois da data em que entrar em execução esta Lei; ficando, porém, obrigados, a titulo de indemnização pela sua alforria, a prestar serviços a seus ex-senhores pelo espaço de três anos.

Veja-se, porém, que essa liberdade não se dava senão com o pagamento de indenização ao proprietário, que, segundo o texto legal, se este "for incapaz de fazê-lo em dinheiro, fica convencionado que os escravos entre 60 e 62 anos trabalharão mais 3 anos, e os demais até aos 65 anos.” (MATTOSO, 2003, p. 179)

No que tange a fixação do preço a ser pago pelos escravos em caso de libertação com pagamento de pecúlio, Gebara (1986, p. 92-3) diz que “à idade declarada na primeira 
matrícula somar-se-ia o tempo decorrido até a segunda matrícula, para a obtenção da idade real do escravo." Essa idade tirada de uma matrícula para a outra era importante, visto que a partir disso seria estipulado o valor do escravo, estabelecendo-se uma tabela de preços.

Para Nabuco (2000) esta tabela significou prejuízo aos escravos, já que tiraria deles algum poder de barganha ou de auxílio de juízes favoráveis a abolição. Pena (1999, p. 258) arrazoa que, com essa tabela feita pelo governo, a situação do escravo nas ações efetivamente piorou, pois os preços colocados eram muito maiores do que os juízes costumavam arbitrar, além do fato de não diferenciar as peculiaridades individuais de cada escravo.

No entanto, conforme os dados levantados por Abrahão (1992) no Arquivo do Centro de Memória da Unicamp, as Ações de Liberdade a partir de 1885 foram mais frequentes:

\begin{tabular}{|c|c|c|}
\hline Períodos das Ações de Liberdade & Qtd & Média Anual \\
\hline Anteriores a 1871 & 005 & - \\
\hline Entre 1871 a 1885 (período que compreende a Lei $\mathrm{n}^{\circ}$ 2040) & 108 & 7,7 \\
\hline Entre 1885 a 1888 (período que compreende a Lei $\mathrm{n}^{\circ}$ 3270) & 044 & 14,7 \\
\hline
\end{tabular}

Assim, o que se viu nas Ações que tramitaram no Tribunal de Campinas foi que a partir da Lei $\mathrm{n}^{\circ} 3.270$ de 28 de setembro de 1885 as ações de liberdade passam a ser mais frequentes, principalmente pela apresentação do pecúlio, mostrando assim que a Lei dos Sexagenários na região de Campinas foi aceita e usada do que a do Ventre Livre.

Os dados da tabela precedente devem provocar a percepção de que eram poucos os escravos que recorriam ao judiciário para concretizarem sua libertação. É de se imaginar que muitos escravos, principalmente aqueles rurais, não ficavam a par das leis que eram confeccionadas positivando seus direitos.

\footnotetext{
É de bom senso que a ignorância da lei escrita fosse generalizada entre os escravos, nem se percebe que canais teriam para adquirir esse saber. Mas, além disto, existem indícios de que a legislação que os protegia era propositalmente ocultada aos escravos, e isso pelo próprio legislador. (CUNHA, 1987, p. 131)
}

Diferentemente, Manuela Carneiro da Cunha (1987, p. 136) defende a posição de que as ideias de alforria chegavam às fazendas, isso devido aos trabalhos que os libertos e não libertos desenvolviam juntos na cafeicultura ou na cana de açúcar, bem como a circulação de escravos às cidades, para prestação de serviços aos seus senhores. 


\begin{abstract}
O meio urbano em muito favoreceu as articulações dos escravos porque ao atrair indivíduos de vários pontos da província, criava uma certa mobilidade para os cativos de mais diferentes propriedades. O contato entre esses indivíduos libertos ou escravos, proporcionava amizades que poderiam resultar em troca de informações e possibilidades de ajuda mútua. Cabia ao escravo, portanto, criar as condições que facilitariam uma negociação com o proprietário que favorecessem a conquista da liberdade. (BERTIN, 2004, p. 105)
\end{abstract}

Esta reflexão é significativa, pois trata do questionamento do senso comum do escravo bestializado, coisificado, menos humano, como se escravos não tivessem construído meios e estruturas de comunicação. Segundo Sidney Chalhoub (2003, p. 41), essa teoria do escravo-coisa tem em contraposição a ideia de Perdigão Malheiro do escravo rebelde. Pois como "vimos em Perdigão Malheiro o escravo que se concebe como uma criatura inferior apresenta como alternativa a essa auto representação o 'ódio', a 'vingança', as 'crueldades'”.

Como pessoas que participaram ativamente do processo para a abolição, seja ativa ou indiretamente, ou seja, por revoltas ou por conversas e reuniões a fim de explicar a situação das novas leis escravistas, podem ser reduzidas a seres bestializados? A percepção de tratamento indevido, capaz de gerar rebeldia, pressupõe também compreensão do meio e comparação com outras experiências e possibilidades.

\begin{abstract}
A violência da escravidão não transformava os negros em seres 'incapazes de ação autônoma', nem em passivos receptores de calores senhoriais, e nem tampouco em rebeldes valorosos e indomáveis. Acreditar nisso poder ser apenas a opção mais cômoda: simplesmente desancar a barbárie social de um outro tempo traz implícita a sugestão de que somos menos bárbaros que hoje em dia, de que fizemos realmente algum 'progresso' dos tempos da escravidão até hoje. A ideia de que 'progredimos' de cem anos pra cá é, no mínimo, angelical e sádica: ela supõe ingenuidade e cegueira diante de tanta injustiça social, e parte também da estranha crença de que sofrimentos humanos intensos podem ser de alguma forma pesados ou medidos." (CHALHOUB, 2003, p. 42)
\end{abstract}

Em que pese os argumentos em contrário, quer parecer que, uma vez que os escravos conseguiam saber das leis postas, eles não ficavam omissos. Engano pensar que o escravo não participava da conquista da sua liberdade. Talvez o meio que alguns escravos/recém-libertos usavam para participar da 'revolução pela liberdade' fosse passar a informação para os que não sabiam das leis, e isso não exclui o fato de estarem participando ativamente no processo de abolição. 


\section{AS AÇÕES DE LIBERDADE}

Como se processavam as ações de liberdade? Segundo Keila Grinberg (1994, p. 223), a ação de liberdade iniciava-se quando o juiz recebia um requerimento, já assinado por uma pessoa livre, a pedido do escravo. O magistrado então nomeava um curador - o escravo não era civilmente capaz de intentar qualquer tipo de ação - e depois de nomeado o curador, o juiz ordenava o depósito - lugar onde o escravo ficava geralmente aos cuidados do curador.

Logo depois, o curador fazia um requerimento contendo as razões alegadas pelo representado para requerer a liberdade, havendo então a possibilidade de resolução amigável da lide, muito embora o que geralmente acontecia era que o advogado ou o procurador do réu (senhor do escravo) enviava outro libelo (requerimento) ou "contrariedades", apresentando a defesa dos interesses do seu cliente.

Então testemunhas eram ouvidas, provas colhidas, laudos eram feitos, de ambos os lados. "Ao final, o juiz apresenta um relatório do processo e divulga o veredicto." O resultando ainda pode sofrer contestação, indo para outras instâncias. "Pela Lei de 71 as Ações de Liberdade deveriam ser sumárias e, em geral foram bem rápidas. A maior parte levou até três meses para atingir seu resultado (na cidade de Campinas)." (XAVIER, 1996, p. 65 - parênteses nossos)

\section{Esquema Geral de uma Ação de Liberdade ${ }^{2}$}

\begin{tabular}{|c|c|}
\hline Primeira Instância & $\begin{array}{l}\text { 1. Petição do escravo requerida por um curador; assinada por qualquer } \\
\text { homem livre. } \\
\text { 2. Nomeação do curador; mandado de apreensão e depósito do escravo. } \\
\text { 3. } \quad \text { Citação do senhor e das testemunhas. } \\
\text { 4. Requerimento de audiência, feito pelo curador. } \\
\text { 5. Apresentação do libelo cível (primeiras razões) do escravo, } \\
\text { assinada pelo curador. } \\
\text { 6. Resposta (ou contrariedades) do réu, assinada por ele mesmo ou por seu } \\
\text { advogado. } \\
\text { 7. Inquirição das testemunhas. } \\
\text { 8. Autos conclusos. } \\
\text { 9. Sentença. } \\
\text { 10. Embargos impostos pela parte perdedora. } \\
\text { 11. Embargos aceitos ou não pelo juiz. } \\
\text { 12. No caso de os embargos terem sido aceitos, nova sentença. } \\
\text { 13. Apelação: se a sentença tiver sido contrária à liberdade, o juiz } \\
\text { apelará ex-officio; se for favorável, a apelação será interposta pelo senhor. } \\
\text { 14. Autos enviados ao Tribunal da Relação. }\end{array}$ \\
\hline
\end{tabular}

\footnotetext{
$\overline{2}$ Quadro formulado com base nos dados de Lenine Naquete, Luis Maria apud Keila Grinberg, "Liberata - a Lei da ambiguidade".
} 


\begin{tabular}{|c|c|c|}
\hline Segunda Instância & & $\begin{array}{l}\text { Apelação recebida no Tribunal da Relação. } \\
\text { Exposição das razões do autor. } \\
\text { Exposição das razões do réu. } \\
\text { Autos lidos por cada membro do tribunal. } \\
\text { Parecer de cada um. } \\
\text { Acórdão da Relação: primeira sentença confirmada ou reformada. } \\
\text { Embargos da parte perdedora. } \\
\text { Embargos aceitos ou não pelos juízes. } \\
\text { No caso de os embargos terem sido aceitos, novo acórdão. } \\
\text { Pedido de revista cível pela parte perdedora. } \\
\text { Autos enviados ao Supremo Tribunal da Justiça. }\end{array}$ \\
\hline
\end{tabular}

\begin{tabular}{|c|c|}
\hline Terceira Instância & $\begin{array}{l}\text { 1. Autos lidos por cada membro do tribunal. } \\
\text { 2. Parecer de cada membro do tribunal. } \\
\text { 3. Pedido de revista cível aceito ou negado (só é aceito em caso de nulidade } \\
\text { ou injustiça notória). } \\
\text { 4. Se aceito, enviado a outro Tribunal da Relação, para revisão do processo. } \\
\text { 5. Este tribunal julga o caso em instância definitiva, com os mesmos } \\
\text { procedimentos do Supremo. } \\
\text { 6. Com a nova sentença (acórdão confirmando ou reformando), o processo é } \\
\text { enviado de volta ao Supremo Tribunal de Justiça. } \\
\text { 7. Divulgação da sentença. }\end{array}$ \\
\hline
\end{tabular}

Os estudos empreendidos por Grinberg (1994) revelaram diferenciação entre juízes de primeira instância e as outras, a saber, o Tribunal da Relação do Rio de Janeiro e Supremo Tribunal de Justiça. A autora aponta mostra a diferença da influência exercida pelos proprietários sobre os magistrados locais, o que difere dos desembargadores (instâncias superiores), pois os mesmos, em sua maioria, viviam na capital, ao redor das influências do imperador.

Grinberg (1994) ainda diz que a maioria das decisões dos juízes de primeira instância era em prol do fazendeiro, ou seja, contrárias à liberdade do cativo. No entanto, quando essa decisão era levada à outra instância, elas eram majoritariamente reformadas, enquanto que os recursos interpostos pelos senhores de escravos, contra a concessão de liberdade em primeira instância, foram majoritariamente negados.

Dentro da Ação de Liberdade, a figura do curador era extremamente importante, pois se o escravo não conseguisse alguém que falasse por ele, não haveria ação. Muitas vezes o 
curador nomeado pelo juiz era a própria pessoa que havia assinado o primeiro requerimento, o solicitador.

[...] para um escravo conseguir um curador é preciso que, antes de tudo, ele conheça homens livres que se disponham a redigir um requerimento em seu nome, a requerer de fato o curador e, possivelmente, a protegê-lo em caso de retaliações do senhor. Não era qualquer um que podia fazer isso. Ele precisaria para tal ter relações pessoais bem consolidadas. (GRINBERG, 1994, p. 69)

Tal questão serve como suporte, entre outras, para a compreensão de que as Ações de Liberdade foram, antes de tudo, instrumentos manejados por abolicionistas operadores do Direito, como advogados, rábulas, delegados, etc. Esta tese certamente merece amparo, em especial ao se verificar o refinamento das articulações legais verificadas em muitas das ações e estudadas por tantos historiadores ${ }^{3}$.

Ainda assim, o papel do escravo que se expunha perante seu senhor, contrapondo-se judicialmente a ele, não pode ser desprezado. Seria o escravo que suportaria o ônus mais pesado desta confrontação, muitas vezes “depositado" em condições desfavoráveis, quando não preso durante o digladiar da Ação de Liberdade.

$\mathrm{Na}$ região de Campinas, a maior parte das Ações de Liberdade era requerida com base na oferta de pagamento baseado na existência de pecúlio juntado (ver tabela abaixo). A formação de pecúlio pelo escravo era uma prerrogativa que seu senhor deveria aceitar para que acontecesse. Muitas vezes, o proprietário ficava com uma parte da quantia ganha pelo escravo, pois cabia ao seu senhor decidir até que ponto o escravo poderia manter a posse de quantias que o ajudariam na conquista da sua liberdade, através do pecúlio. Apesar de todos os percalços, o escravo tinha no direito costumeiro, desde antes da legislação de 71 e 85, a prerrogativa de juntar pecúlio para sua possível liberdade.

Equivale a dizer que o senhor julgou tacitamente o escravo capaz de possuir bens, e isto explica que o cativo possa ter outras posses além de dinheiro, até mesmo escravos, e como alguns deles chegaram a fazer testamento, embora não possuíssem qualquer personalidade jurídica e nenhum direito legal à propriedade. (MATTOSO, 2003, p. 189)

\footnotetext{
3 Merece especial destaque o trabalho de Luiz Gama, abolicionista paulista e rábula, cujo trabalho em favor da libertação de escravos por meio dos meios judiciais mereceu destaque e tem sido mais amiúde estudado. Luiz Gama trabalhou como amanuense - escriturário - de um delegado na cidade de São Paulo, e ainda no exercício desta função começou a trabalhar em defesa dos escravos, o que, como se pode imaginar, foi a razão do seu desligamento da função. (COVOLAN; FABRICIO, 2014)
} 
Tabela 1 Formas de obtenção de liberdade em Campinas ${ }^{4}$

\begin{tabular}{|c|c|c|}
\hline Tipos de Ação & Quantidade & $\mathbf{\%}$ \\
\hline Liberdade por pecúlio & $\mathbf{7 5}$ & $\mathbf{4 7 , 8}^{*}$ \\
\hline Depósito de pecúlio & 19 & 12,1 \\
\hline Manutenção de liberdade & 14 & 08,9 \\
\hline Tráfico ilegal & 07 & 04,5 \\
\hline Fundo de emancipação & 07 & 04,5 \\
\hline Outras & 35 & 22,2 \\
\hline
\end{tabular}

*Em $61 \%$ desses casos consta avaliação de escravos

Como demonstrado acima, a forma mais recorrente de alforria era por pecúlio. No entanto, "essas práticas beneficiam o escravo urbano, o doméstico, o mineiro. Mas desfavorecem a grande maioria do povo dos escravos: os que vivem no campo" (MATTOSO, 2003, 189), o que não excluía a hipótese dos rurais conseguirem pagar por sua liberdade.

Os escravos rurais se diferenciavam dos urbanos. As atividades laborais dos escravos das cidades faziam com que eles tivessem maior possibilidade de acumulação de pecúlio. Um escravo da fazenda tinha mais dificuldade em juntar esmolas ou fazer algum tipo de comércio, sem contar as ocupações que só "rendiam" nas cidades, como alfaiates, engraxates, comerciantes, carpinteiros, entre outras.

As ações de liberdade individuais eram as que mais facilmente se viam aceitas e deferidas. Muitos dos que tentaram algum tipo de alforria coletiva não conseguiram a liberdade, ao menos na cidade de Campinas.

Para se ter uma ideia, das 99 pessoas que conseguiram se libertar, 90 o fizeram por Ações Individuais. Casos em que uma única Ação libertava um grupo de escravos eram raros. Apenas em dois processos os envolvidos somavam de uma só vez 7 escravos e houve apenas um caso em que este número subiu para 9. (XAVIER, 1994, p. 56)

No ano de 1888 a cidade de Campinas possuía quatro ofícios judiciais, mas as Ações de Liberdade concentraram-se nos três primeiros, num total de 157 ações. Destas, 58 traziam a profissão do escravo que estava sendo curatelado para a liberdade, sendo que em 42 delas as profissões revelam o exercício de labores citadinos, enquanto apenas 16 indicam trabalhos rurais. Entre as 42 atividades que eram exercidas no meio urbano, destacam-se: cozinheira(o) e trabalhos domésticos, com 9 e 11 pessoas, respectivamente. Embora nem

4 Tabela retirada do livro "As Ações de Liberdade de Escravos do Tribunal de Campinas" (ABRAHÃO, 1992, p. 7) 
sempre constante dos processos, tudo leva a crer que a indicação da profissão do escravo visava justificar, dentro do processo, sua condição de obter pecúlio. (ABRAHÃO, 1992)

No estudo feito nas ações depositadas no Arquivo do Tribunal de Justiça de Campinas, predominam escravas como requerentes, e a idade predominante, curiosamente, foi a de maior capacidade laboral: entre 19-29 anos. Apesar disso, a segunda faixa de idade predominante foi entre 40-49 anos, considerada idade avançada em tempos de baixíssima expectativa de vida. ${ }^{5}$

Maria, por exemplo, era escrava nascida na África e tinha 40 anos quando apareceu no Tribunal de Campinas para requerer sua liberdade no ano de 1872 . Sendo assim, ao que tudo indica, Maria foi traficada ilegalmente entre o ano de 1831 e 1850, mas esta não foi a razão de pedir da Ação de Liberdade ${ }^{6}$.

No momento da propositura da ação, Maria pertencia ao espólio de Francisco José Martins de Abreu, e consta que exercia trabalhos domésticos e requereu sua liberdade com base na Lei de 1871, oferecendo o pagamento de pecúlio. Neste caso particular era mais fácil, já que o inventário significara a avaliação prévia de Maria. Assim, a requerente foi reavaliada e, sendo aceito o valor pelo juiz, foi libertada. ${ }^{7}$

Em que pese o fato de haver avaliação dentro do inventário, há resistência do representante do espólio, sendo necessária a realização de avaliação. Por outro lado, ainda que tenha havido resistência do proprietário, Maria alcança seu intento, tendo o judiciário e a lei escrita ao seu favor.

Innocencia, de 70 anos de idade, entra em Campinas com Ação de Liberdade para apresentação de pecúlio, por meio de seu solicitador Francisco de Paula Pereira Mendes e 1873.

No caso de Innocencia, não foi ela a oferecer o pecúlio para sua própria liberdade, mas seu filho, que era liberto e exercia atividade de capitão. Veja-se que, embora liberto, portanto capaz, não é seu filho quem figura como solicitador ou curador, e que expressamente se fez constar dos autos a procedência do pecúlio, bem como a condição de liberto do pagante, e sua profissão, como a atestar não ser este um vadio. ${ }^{8}$

\footnotetext{
Os dados obtidos por Xavier na pesquisa que desenvolveu com dados da Cidade de São Paulo são coincidentes: número majoritário de mulheres requerentes nas Ações de Liberdade.

${ }^{6}$ Como analisado em outro artigo, o pleito de liberdade com base em tráfico ilegal, tendo por fundamento legal a Lei de 1831, surge mais amiúde a partir da década de 1860 , em especial pela pena de Luiz Gama. (COVOLAN; FABRÍCIO, 2014). No entanto, a cidade de Campinas viu poucas Ações com base em tal argumento legal, e mesmo nestas não houve sucesso. $7 \mathrm{TJC}, 1^{\circ} \mathrm{OF} / \mathrm{CX} 204,4265$ - Centro de Memória da Unicamp.

8 TJC, $1^{\circ} \mathrm{OF}, \quad \mathrm{CX} 210,4348 \quad-$ Centro de Memória da Unicamp.
} 
Não era incomum que membros da família do escravo requerente pagassem, ou ajudassem de alguma forma no pagamento de sua alforria. Além de familiares, como visto acima, outros estudos referem terceiros - provavelmente ligados ao movimento abolicionista, padrinho ou madrinha, ou parentes do próprio proprietário. E mais uma vez se vê a forte importância dos laços com livres e influentes. (BERTIN, 2004, p. 116)

Nessas relações entre terceiros pagantes, existia ainda o fato de ligações sanguíneas ou afetiva com os escravos, como o caso de Adão com quatro anos, filho de uma escrava. Seu pai, livre, não apenas pagou a indenização ao senhor, como também o declarou seu herdeiro universal. (BERTIN, 2004, p. 120)

Como se viu, a Lei de 1871 impusera aos proprietários a obrigação de matricular seus escravos, sob pena de ser proposta Ação de Liberdade, quando inexistente a matrícula. A norma que indicara a obrigação de registro dos escravos fora defendida no governo brasileiro imperial por Perdigão Malheiro (1976, p. 167-68), quando refletira sobre o inevitável processo de emancipação da mão de obra escrava:

\begin{abstract}
Uma providência, porém, de grande alcance, seria a matrícula ou registro geral de todos os escravos do Império, quer das cidades e povoados, quer do campo: medida indispensável, se se marcar dia certo para a emancipação, [...]; e conveniente, quando mesmo tal prazo se não fixe desde já, porque esse registro dará o recenseamento exato da população escrava, o de cada sexo, idade, estado, etc., o que deve concorrer poderosamente para se melhor providenciar de futuro, a fim de proferir a última palavra do problema. O meio mais eficaz de o conseguir será, não tanto a multa e a prisão pela omissão, mas sobretudo a declaração de que os não matriculados dentro de 5 anos, v. g., da data da lei, serão reputados livres[...]: digo cinco anos, porque é este o prazo da prescrição aquisitiva da liberdade por nosso Direito, prescrição que começaria nesse caso a correr da data da mesma lei, e além disto para que os senhoras não tenham razão ou pretexto de queixa, como sucederia se o prazo fosse breve.
\end{abstract}

A falta de registro e a possibilidade daí decorrente de requerimento de liberdade fundamentou o pedido de Maria Theodora ${ }^{9}$, de 19 anos, escrava de Maria Hypolita da Cruz. A escrava entrou, em Campinas, com a Ação de Liberdade pela não efetuação de Matrícula de Escravos, em acordo com a Lei 2040 , art. $8^{\circ}$ parágrafo $2^{\circ}$, sendo seu solicitador Francisco Glycerio de Cerqueira Leite ${ }^{10}$. Foi nomeado como seu curador Luiz Silverio Alves Cruz, sendo ele mesmo seu depositário. De 22 de maio a 23 de outubro de 1880 o processo se desenvolveu, demonstrando, aliás, a celeridade com que eram realmente tratadas essas

\footnotetext{
9 TJC, $2^{\circ} \mathrm{OF}, \mathrm{CX} 95$. Centro de Memória da Unicamp

10 Francisco Glycério Cerqueira Leite é o nome que aparece com mais frequência nas ações de liberdade de Campinas, majoritariamente como defensor ou curador de escravos, e sua história na cidade marcou-se pela defesa da abolição e posteriormente em prol da luta ao lado dos republicanos. No entanto, importa ressaltar que, diferentemente de Luiz Gama em São Paulo, Glycério não atuou exclusivamente em defesa de escravos, aparecendo como advogado de senhores de escravos em alguns dos processos. (ABRAHÃO, 1992)
} 
demandas, se não pelo interesse do escravo, em prol dos interesses do senhor, que ficava desprovido do trabalho do escravo, depositado fora de seu alcance. Por fim, o Juiz Herculano Augusto de Padua e Castro proferiu sentença declarando Maria Theodora liberta.

Por fim, resta exemplificar uma Ação de Liberdade fundada nos recursos provenientes do Fundo de Emancipação.

\footnotetext{
Uns quinze anos antes da abolição, um estatuto imperial institui um 'fundo de emancipação' destinado à emancipação. Este fundo nutre-se de taxas pagas sobre os escravos, impostos sobre a transmissão, da propriedade dos cativos, subscrições, donativos, legados. Na verdade, sempre esteve insuficientemente provido. (MATTOSO, 2003, p. 179)
}

Apesar de insuficientemente provido, é com base neste Fundo que José Rodrigues Ferraz do Amaral, coletor de Rendas de Campinas, solicita a liberdade de Maria, de 35 anos, escrava de Cerino Rodrigues. Embora não tenha obtido sua liberdade na cidade de Campinas, consta do processo que a ação foi anulada por já ter sido concedida liberdade, com base no mesmo Fundo, na cidade de Limeira ${ }^{11}$, distante cerca de $55 \mathrm{~km}$ de Campinas.

Estes processos demonstram que as normas criadas para tentar conduzir o processo abolicionista de modo controlado pelo Império, considerando-se as controvérsias entre liberais e conservadores, tiveram efeitos vários, em parte provavelmente não previstos pelos seus articuladores.

José Bonifácio apud Perdigão Malheiro (1976, p. 173), em que pese as motivações várias para o apregoar abolicionista, afirmava mesmo que "sem liberdade individual, [...] não pode haver civilização nem sólida riqueza; não pode haver moralidade e justiça; e sem estas filhas do Céu, não há nem pode haver brio, força e poder entre as Nações."

\section{CONSIDERAÇÕES FINAIS}

A proposta inicial para elaboração deste trabalho foi verificar o papel do escravo como agente idealizador e atuante na conquista de sua liberdade, assim trazendo uma concepção diferente de um escravo-coisa, ou um negro que é reduzido a um animal, que acreditaria e colocaria para si como verdade o modo como era tratado. Pela pesquisa posta,

$\overline{11}$ TJC, $1^{\circ} \mathrm{OF}, \mathrm{CX} 280,5454$ - Centro de Memória da Unicamp 
percebe-se que apesar da influência pesada, com chicotes e açoites, havia escravos que viam seus direitos e fariam o possível para obtê-los.

Verificou-se que as mulheres apareceram de forma marcante na conquista de liberdade; os escravos urbanos se sobressaíram sobre os escravos rurais no que diz respeito à obtenção de pecúlio e consequentemente o pagamento de sua liberdade; a idade, com referência em Campinas, não foi habitualmente a dos extremos, ou seja, crianças e idosos como mais beneficiados com a liberdade, e sim as pessoas de 18 a 29 anos, seguidos da faixa etária de 40 a 49.

Os escravos estavam, ao menos parte deles, buscando aspectos de cidadania, como propriedades para si, constituir família, ter seus cultos e reuniões de acordo com sua cultura, confirmando assim, que eles lutavam por construir os espaços possíveis de uma incipiente cidadania, num tempo em que a ideia da servidão estava incutida fortemente no senso comum, inclusive dos próprios escravos.

As leis de 1871 e 1885 romperam com o poder absoluto do senhor sobre a liberdade de seus escravos, que passaram a poder se utilizar de vias legais para a requisição de sua liberdade, inclusive discutindo em juízo seu valor, e requerendo avaliação de terceiro que não o proprietário.

Sem dúvida, o recurso às vias judiciais era uma maneira indireta de confirmação da própria escravidão, já que a liberdade apenas era viável com o ressarcimento ao senhor, mas significou também, naquele tempo e naquelas condições, que alguns dos escravos puderam sair antecipadamente da condição de propriedade alheia, confrontando seus senhores e saindo de seu domínio.

As leis em questão, bem como as Ações de Liberdade, também revelam a existência de espaços sociais dentro dos quais os escravos agiam para obterem proventos exclusivos, o que parece revelar que dentro de uma condição generalizada de submissão absoluta, houve espaços intermediários em que alguns escravos exerciam mais livremente sua existência. $\mathrm{E}$ foram essas possibilidades, antes consentidas dentro do poder exclusivo do senhor que se tornaram arma de luta judicial após a positivação do direito de libertação por pagamento do valor do escravo.

Assim, embora de pequeno número, essas ações permitem vislumbrar estratégias de confrontação com o escravismo brasileiro dentro das próprias regras do sistema, o que pode ter servido, junto com as demais forças operantes, para a vinda da abolição geral apenas dois anos e oito meses após a criação da denominada Lei dos Sexagenários. 
O silêncio das leis do Estado não caracterizava o silêncio escravo. Resistir aos chicotes; não ceder aos proprietários nem aos governantes; ser forte em meio a uma nova cultura, que subjugava todo e qualquer um que se colocasse contra ela, fazia do escravo, desde o desembarque, um vencedor. E essa vitória era única e exclusivamente do escravo. Por mais que abolicionistas existissem no Brasil, dentro e fora da Academia, que mudara pouco a pouco seu parecer quanto à continuidade da escravidão, o mérito é do negro que angariou a ajuda de advogados, curadores, pessoas livres, levando-os a se engajarem na construção de um país sem escravidão.

\section{REFERÊNCIAS BIBLIOGRÁFICAS}

ABRAHÃO, Fernando Antonio. As Ações de Liberdade de Escravos do Tribunal de Campinas. Campinas, SP: Coleção Instrumentos de Pesquisa: 1992.

BERTIN, Enidelce. Alforrias na São Paulo do Século XIX: Liberdade e Dominação. São Paulo: Humanitas/FFLCH/USP, 2004.

CHALHOUB, Sidney. Visões da Liberdade: Uma história das últimas décadas da escravidão na Corte. São Paulo: $5^{\circ}$ reimpressão. Companhia de Letras, 2003

COVOLAN, Fernanda Cristina; FABRICIO, Matheus Di Felippo. Interpretações da Lei de 07 de novembro de 1831 no Brasil imperial: um estudo de caso. In AGRA, Giscardi Farias; FONSECA, Ricardo Marcelo; SIQUEIRA, Gustavo Silveira.(coords) História do Direito I. Florianópolis: Conpedi/ Boiteux. 2014.

CUNHA, Manuela Carneiro Da. Antropologia do Brasil: mito, história, etnicidade. 2ed. São Paulo: Brasiliense, 1987.

GEBARA, Ademir. O mercado de trabalho livre no Brasil (1871-1888). São Paulo: Brasiliense, 1986.

GRINBERG, Keila. Liberata, a lei da ambiguidade: As ações de liberdade da Corte de Apelação do Rio de Janeiro no século XIX. Rio de Janeiro: Relume-Dumará, 1994.

MALHEIRO, Perdigão. A Escravidão no Brasil: Ensaio Histórico, Jurídico, Social, III Parte e Apêndice. Volume II. Petrópolis, RJ: Vozes Ltda, 1976.

MATTOSO, Katia M. de Queirós; trad. James Amado. Ser Escravo no Brasil. São Paulo: Brasiliense, 2003. 
NABUCO, Joaquim. O abolicionismo. São Paulo : Publifolha, 2000. (Grandes nomes do pensamento brasileiro da Folha de São Paulo). texto básico digitalizado por Sérgio Simonato Campinas/SP. PDF. Acessado em 05/05/2013.

PENA, Eduardo Spiller. O Jogo da Face: A Astúcia Frente aos Senhores e à Lei na Curitiba Provincial. Curitiba, PR: Aos Quatro Ventos, 1999.

XAVIER, Regina Célia Lima. A Conquista da Liberdade: Libertos em Campinas na segunda metade do Século XIX. Campinas, SP: Campiniana, 1996. 